\title{
WFSBP Treatment Guidelines and the problem of evidence grading
}

\author{
Hans Jürgen Möller \\ From $1^{\text {st }}$ International Congress on Neurobiology and Clinical Psychopharmacology and European \\ Psychiatric Association Conference on Treatment Guidance \\ Thessaloniki, Greece. 19-22 November 2009
}

The World Federation of Societies of Biological Psychiatry (WFSBP) has developed several drug treatment guidelines. The following guidelines have either been published already or will be published soon [1-8]

Published: 22 April 2010

\section{References}

1. Bauer M, Whybrow PC, Angst J, Versiani M, Möller HJ: Acute and continuation treatment of major depressive disorder: WFSBP Task Force on Treatment Guidelines for Unipolar Depressive Disorders. World I Biol Psychiatry 2002, 3:5-43, World J Biol Psychiatry 3: 69-86.

2. Bauer M, Bschor T, Pfennig A, Whybrow PC, Angst J, Ersiani M, Möllerhj : Treatment of unipolar depressive disorders in primary care: WFSBP Task Force on Unipolar Depressive Disorders. World Federation of Societies of Biological Psychiatry (WFSBP) Guidelines for Biological Treatment of Unipolar Depressive Disorders in Primary Care. World J Biol Psychiatry 2007, 8(2):67-104.

3. Falkai P, Wobrock T, Lieberman J, Glenthoj B, Gattaz WF, Möller HJ, WFSBP Task Force on Treatment Guidelines for Schizophrenia: Acute and longterm treatment of schizophrenia: World Federation of Societies of Biological Psychiatry (WFSBP) Guidelines for Biological Treatment of Schizophrenia, Part 1: Acute treatment of schizophrenia. World J Biol Psychiatry 2005, 6(3):132-191.

4. Falkai P, Wobrock T, Lieberman J, Glenthoj B, Gattaz WF, Möller HJ: WFSBP Task Force on Treatment Guidelines for Schizophrenia+ 2006: World Federation of Societies of Biological Psychiatry (WFSBP) Guidelines for Biological Treatment of Schizophrenia, Part 2: Long-term treatment of schizophrenia. World J Biol Psychiatry 7(1):5-40.

5. Bandelow B, Zohar J, Hollander E, Kasper S, Möller HJ, WFSBP TASK FORCE ON TREATMENT GUIDELINES FOR ANXIETY OBSESSIVE-COMPULSIVE POSTTRAUMATIC STRESS DISORDERS: Treatment of Anxiety, ObsessiveCompulsive and Post-Traumatic Stress Disorders: World Federation of Societies of Biological Psychiatry (WFSBP) Guidelines for the Pharmacological Treatment of Anxiety, Obsessive-Compulsive and PostTraumatic Stress Disorders. World J Biol Psychiatry 2008, 9(4):248-312.

6. Grunze H, Kasper S, Goodwin G, Bowden C, Baldwin D, Licht RW, Vieta E, Moller HJ: Treatment of bipolar depression, treatment of mania and maintenance treatment of bipolar disorder: The World Federation of Societies of Biological Psychiatry (WFSBP) Guidelines for the Biological Treatment of Bipolar Disorders, Part II: Treatment of Mania. World J Biol Psychiatry 2003, 4:5-13, GRUNZE H, KASPER S, GOODWIN G, BOWDEN C, MOLLER HJ (2004): The World Federation of Societies of Biological

Psychiatric Department, Ludwig-Maximilians University, Munich, Germany
Psychiatry (WFSBP) guidelines for the biological treatment of bipolar disorders, part III: maintenance treatment. World J Biol Psychiatry 5: 120-135. GRUNZE H, KASPER S, GOODWIN G, BOWDEN C, BALDWIN D, LICHT R, VIETA E, MÖLLER HJ (2002): World Federation of Societies of Biological Psychiary (WFSBP) guidelines for biological treatment of bipolar diorders, Part I: Treatment of bipolar depression. World J Biol Psychiatry 3: 115-124..

7. Herpertz SC, Zanarini M, Schulz CS, Siever L, Lieb K, Möller HJ, WFSBP Task Force on Personality Disorders: Treatment of personality disorders: World Federation of Societies of Biological Psychiatry (WFSBP) Guidelines for Biological Treatment of Personality Disorders. World J Biol Psychiatry 2007, 8(4):212-244.

8. Grunze H, Vieta E, Goodwin G, Bowden C, Licht RW, Möller HJ, Kasper S: Treatment of acute bipolar depression: The World Federation of Societies of Biological Psychiatry (WFSBP) Task Force on Treatment Guidelines for Bipolar Disorders. World I Biol Psychiatry 2009, WFSBP guidelines are developed by special WFSBP task forces which include members of the WFSBP as well as non-WFSBP colleagues seen as international experts in the relevant field. The task forces are composed with the aim to include knowledge and experience in the guidelines from every part of the world, not only the western hemisphere. The core characteristic of the evidence criteria is that meta-analyses are not seen as the most important factors for a high grade of evidence, but the results of well-designed studies. This approach is closer to the decision process of the most important regulatory authorities such as the FDA or the EMEA/ CPMP. Recently the evidence criteria have been optimised (Bandelow B, Zohar J, Kasper S, Möller HJ (2008): World J Biol Psychiatry 9(4): 242-247.)..

doi:10.1186/1744-859X-9-S1-S43

Cite this article as: Möller: WFSBP Treatment Guidelines and the problem of evidence grading. Annals of General Psychiatry 2010 9(Suppl 1):S43.

Submit your next manuscript to BioMed Central and take full advantage of:

- Convenient online submission

- Thorough peer review

- No space constraints or color figure charges

- Immediate publication on acceptance

- Inclusion in PubMed, CAS, Scopus and Google Scholar

- Research which is freely available for redistribution

Submit your manuscript at www.biomedcentral.com/submit 